Provided for non-commercial research and education use. Not for reproduction, distribution or commercial use.

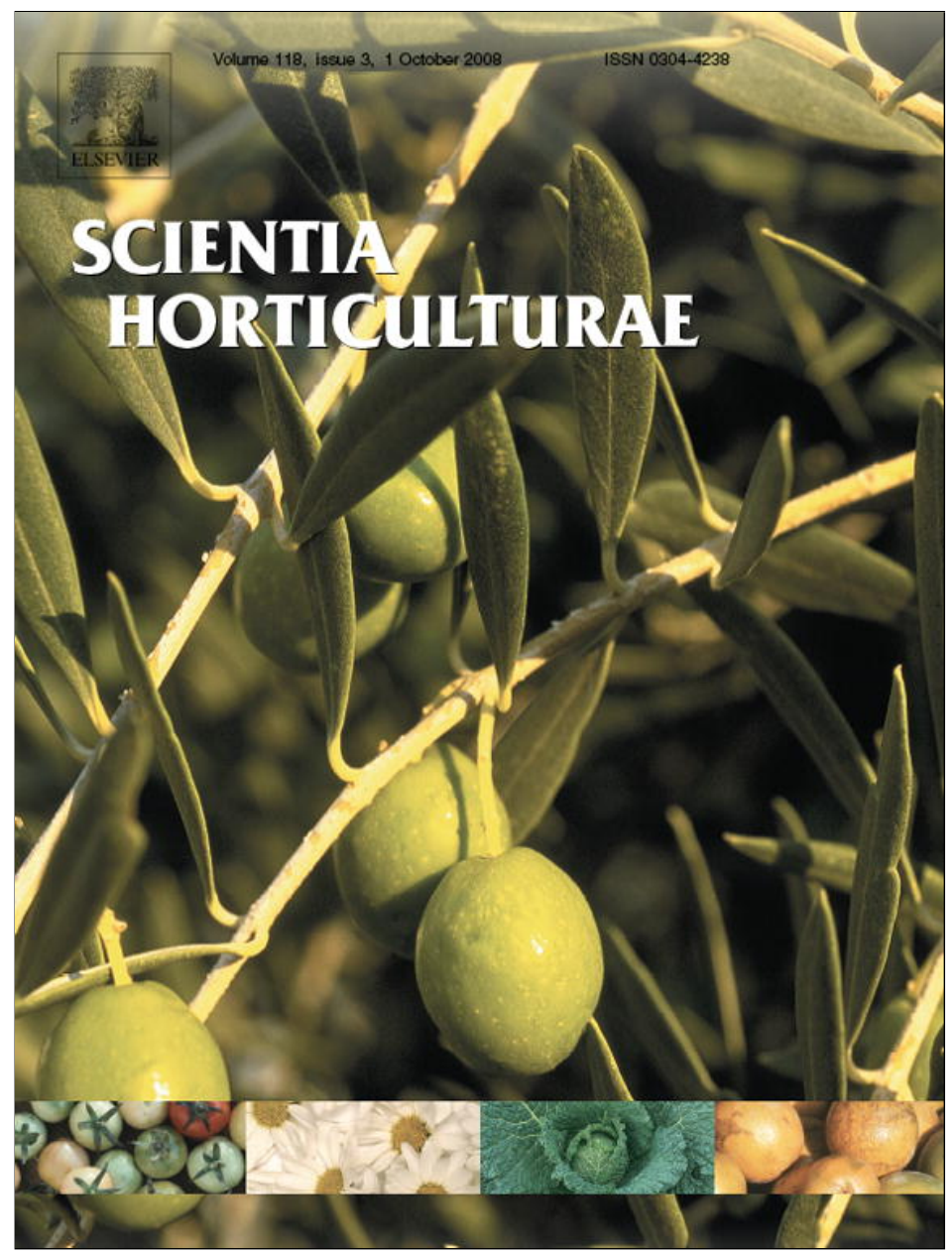

This article appeared in a journal published by Elsevier. The attached copy is furnished to the author for internal non-commercial research and education use, including for instruction at the authors institution and sharing with colleagues.

Other uses, including reproduction and distribution, or selling or licensing copies, or posting to personal, institutional or third party websites are prohibited.

In most cases authors are permitted to post their version of the article (e.g. in Word or Tex form) to their personal website or institutional repository. Authors requiring further information regarding Elsevier's archiving and manuscript policies are encouraged to visit:

http://www.elsevier.com/copyright 


\title{
Analysis of genetic diversity in Portuguese Ceratonia siliqua L. cultivars using RAPD and AFLP markers
}

\author{
P. Barracosa ${ }^{\mathrm{a}, *}$, M.B. Lima ${ }^{\mathrm{b}}$, A. Cravador ${ }^{\mathrm{c}, \mathrm{d}, 1}$ \\ a Departamento de Produção Vegetal, Escola Superior Agrária de Viseu - ISPV, Quinta da Alagoa - Ranhados, 3500 Viseu, Portugal \\ ${ }^{\mathrm{b}}$ Unidade de Taxonomia Numérica, Estação Agronómica Nacional, Quinta do Marquês, 2784-505 Oeiras, Portugal \\ ${ }^{\mathrm{C}}$ Universidade do Algarve-FERN, Campus de Gambelas, 8005-139 Faro, Portugal \\ d IBB/CGB-UTAD Apartado 10103, Vila Real 5001, Portugal
}

\section{A R T I C L E I N F O}

\section{Article history:}

Received 6 November 2007

Received in revised form 7 April 2008

Accepted 1 June 2008

$$
\begin{aligned}
& \text { Keywords: } \\
& \text { RAPD } \\
& \text { AFLP } \\
& \text { Genetic diversity } \\
& \text { Carob } \\
& \text { Ceratonia siliqua } \\
& \text { Leguminosae }
\end{aligned}
$$

\begin{abstract}
A B S T R A C T
Although carob (Ceratonia siliqua L.) is of great economic importance little is still known about the pattern of genetic variation within this species. Morphological characteristics based on 31 fruit and seeds of continuous characters determinant for agro-industrial uses, were compared with RAPD and AFLP markers for assessing genetic distances in 68 accessions of carob trees, from different cultivars, varieties and eco-geographic regions of Algarve. Eighteen selected RAPD primers applied to the 68 accessions produced a total of 235 fragments ranging from 200 to $2000 \mathrm{bp}$, of which 93 (40\%) were polymorphic. Four AFLP selective primer combinations generated a total of 346 amplification fragments of which 110 were polymorphic. The average level of polymorphism based on four primer combinations was $31.8 \%$. The phenetic trees based on RAPD and AFLP analyses gave high co-phenetic correlation values, and were found to be consistent in general with the analysis of morphological data, carried out on the same accessions. A number of RAPD and AFLP markers were found to be diagnostic for 'Canela' cultivar and 13 wild ungrafted trees.
\end{abstract}

(c) 2008 Elsevier B.V. All rights reserved.

\section{Introduction}

Ceratonia siliqua L. is one of the most characteristic trees of the maquis from the Mediterranean basin, especially at low altitude [0-300 (sometimes 500) rarely $800 \mathrm{~m}$ ] and constitutes with Olea, Laurus and Myrtus the xerotopical Indo-Malesian flora (Zohary, 1973). Carob has a significant economic importance for Algarve, the Southern region of Portugal, accounting for $14 \%(40,100 t)$ of the world annual production (Graça and Custódio, 2000).

Domestication of $C$. siliqua in Algarve region promoted a production of large fruits with high sugar content for human and animal nutrition that resulted in a limited number of cultivars. The principal carob cultivars of Portugal, namely 'Mulata', 'Galhosa', 'Aida' and 'Lagoinha' were recently characterized based on 61 descriptors of the tree, leaf, inflorescence, fruit and seed (Barracosa and Graça, 2006). Wild ungrafted trees originated from seeds by natural cross-pollinated sexual reproduction, giving rise to a wide

\footnotetext{
* Corresponding author. Tel.: +351232 480600; fax: +351232426536. E-mail addresses: pbarracosa@esav.ipv.pt, pbarracosa@gmail.com (P. Barracosa), acravad@ualg.pt (A. Cravador).

${ }^{1}$ Tel.: +351 289 800935; Fax: +351289 818419 .
}

variety of plants that have been developed with the purpose of increasing seed yield and gum quality. The most widely used carob product in the food industry, is the Locust Bean Gum (LBG), which is a galactomannan used as a natural food additive (E 410). Besides its economical importance this species has great ecological significance as it can be used in reforestation of arid and degraded areas growing well in marginal soils not adapted to other agricultural species (Winer, 1980). In 2003-2004 the Algarve region suffered great forest fires which devastated an extensive area. Carob trees were responsible for limiting the propagation of fire and a significant part of this burnt area could be occupied by new carob plantations. Besides the plantation of a high number of trees in the last 10 years we can expect a tendency for an increase. Natural antioxidants contained in the seed coat and pulp fruit are potential new products to be used in the food industry (Batista and Amaral, 1996; Makris and Kefalas, 2004) and carob is actually considered a plant to investigate for new antioxidants (Alali et al., 2007). Carob pods are presently explored also as material for the production of bioethanol, with several advantages in comparison to other agricultural crops rich in sugar (Vourdoubas et al., 2002).

The increasing risk of genetic erosion of the carob genetic resources due to anthropic pressure, namely urbanistic development and to forest fires in the Mediterranean region, make it 
urgent to study and describe the actual consistency of carob germoplasm. The knowledge of genetic variability within a taxa, can be used to complement phenotypic information, and is a fundamental tool to preserve the biodiversity, because it permits organization of germoplasm and provides more efficient genotype sampling (Nienhuis et al., 1993). Carob cultivars can be characterized using a combination of phenotypical and genotypical characteristics. Morphological and physiological characters are important and have been traditionally used for the identification of carob varieties (Tous and Battle, 1990). However, traditional cultivar identification based on morphological and physiological traits requires a large set of phenotypic data that are often difficult to assess and sometimes variable due to environmental influences, which may lead to unreliable or erroneous determination. Furthermore, variation in fruit and flower characters, which is important in the definition of a cultivar, can be discerned only in adult trees, precluding their use in the identification of young plants (Tous and Battle, 1990). Morphological evaluation and characterization of carob cultivars in Algarve region were recently published (Barracosa et al., 2007).

Biochemical assays are limited by the number of polymorphic loci detected and give no direct assessment of the potential variation present in the genome. Isoenzyme analyses in carob have shown low polymorphism between cultivars either of different (Tous et al., 1992; Battle et al., 1997) or same origin and did not reveal specific biochemical markers for carob cultivars from Algarve (Barracosa, unpublished results). Recently the genetic diversity in Tunisian natural populations from four bioclimatic zones based on allozyme analysis was evaluated. The results showed high diversity within populations and high genetic similarities between populations, which indicated that populations have been recently isolated due to anthropic pressure (Makrem et al., 2006). The RAPD analysis was also used in seminatural carob populations from Lebanon. The results indicated that the populations did not cluster based on geographic proximity and revealed a significant difference between and within populations, suggesting that the remaining populations constitute a valuable germoplasm (Talhouk et al., 2005). In the present work we have applied RAPD and AFLP techniques to assess the genetic variation in the nine main carob cultivars and different wild trees of Algarve and compared them with morphological analysis.

\section{Materials and methods}

\subsection{Plant material}

The analyses were carried out on 68 trees of C. siliqua distributed over the main carob plantations in Algarve, which were selected on the basis of a preliminary morphological and physiological evaluation of this taxon. Seventeen trees belong to the experimental field of the Regional Agricultural Centre of Algarve (DRAALG) located in Tavira. They include the principal Portuguese cultivars 'Mulata' (accession $\mathrm{n}^{\circ} 13$ ), 'Galhosa' (115), 'Lagoinha' (126), 'Canela' (129), 'Costela Vaca' (147, 151), 'Alfarroba Burro' (149), 'Aida' (170), three Spanish cultivars 'Rojal' (124),

Table 1

Accessions of the carob trees used in morphological, RAPD and AFLP analysis

\begin{tabular}{|c|c|c|c|c|c|c|c|c|c|}
\hline \multicolumn{5}{|c|}{ Geographic location } & \multicolumn{5}{|c|}{ Geographic location } \\
\hline Code & Cultivars & Latitude (N) & Longitude (W) & Origin & Code & Cultivars & Latitude (N) & Longitude (W) & Origin \\
\hline MlA1 & Mulata (Ml) & $37^{\circ} 05^{\prime} 37^{\prime \prime}$ & $08^{\circ} 16^{\prime} 34^{\prime \prime}$ & Albufeira (A) & BrSa120 & Brava (Br) & $37^{\circ} 06^{\prime} 58^{\prime \prime}$ & $07^{\circ} 39^{\prime} 29^{\prime \prime}$ & S.B. Alp. (Sa) \\
\hline MlA2 & Mulata (Ml) & $37^{\circ} 05^{\prime} 38^{\prime \prime}$ & $08^{\circ} 16^{\prime} 41^{\prime \prime}$ & Albufeira (A) & BrLa121 & Brava $(\mathrm{Br})$ & $37^{\circ} 06^{\prime} 58^{\prime \prime}$ & $07^{\circ} 39^{\prime} 29^{\prime \prime}$ & Lagoa (La) \\
\hline MlA3 & Mulata (Ml) & $37^{\circ} 05^{\prime} 41^{\prime \prime}$ & $08^{\circ} 16^{\prime} 38^{\prime \prime}$ & Albufeira (A) & $\mathrm{BrC} 122$ & Brava (Br) & $37^{\circ} 20^{\prime} 13^{\prime \prime}$ & $07^{\circ} 29^{\prime} 59^{\prime \prime}$ & C. Marim (C) \\
\hline MlLg5 & Mulata (Ml) & $37^{\circ} 08^{\prime} 11^{\prime \prime}$ & $08^{\circ} 42^{\prime} 41^{\prime \prime}$ & Lagos (Lg) & CtLg123 & Cutelôa (Ct) & $37^{\circ} 08^{\prime} 43^{\prime \prime}$ & $08^{\circ} 46^{\prime} 02^{\prime \prime}$ & Lagos (Lg) \\
\hline MlA6 & Mulata (Ml) & $37^{\circ} 11^{\prime} 01^{\prime \prime}$ & $08^{\circ} 12^{\prime} 38^{\prime \prime}$ & Albufeira (A) & RjE124 & Rojal (Rj) & $37^{\circ} 06^{\prime} 58^{\prime \prime}$ & $07^{\circ} 39^{\prime} 29^{\prime \prime}$ & Spain (E) \\
\hline MlC8 & Mulata (Ml) & $37^{\circ} 18^{\prime} 47^{\prime \prime}$ & $07^{\circ} 27^{\prime} 10^{\prime \prime}$ & C. Marim (C) & BrL125 & Brava $(\mathrm{Br})$ & $37^{\circ} 10^{\prime} 50^{\prime \prime}$ & $07^{\circ} 59^{\prime} 20^{\prime \prime}$ & Loulé (L) \\
\hline MIL9 & Mulata (Ml) & $37^{\circ} 04^{\prime} 39^{\prime \prime}$ & $07^{\circ} 59^{\prime} 40^{\prime \prime}$ & Loulé (L) & PlLg126 & Lagoinha(Pl) & $37^{\circ} 06^{\prime} 58^{\prime \prime}$ & $07^{\circ} 39^{\prime} 29^{\prime \prime}$ & Lagos (Lg) \\
\hline MlA12 & Mulata (MI) & $37^{\circ} 09^{\prime} 43^{\prime \prime}$ & $08^{\circ} 10^{\prime} 58^{\prime \prime}$ & Albufeira (A) & $\mathrm{BrF} 127$ & Brava (Br) & $37^{\circ} 06^{\prime} 58^{\prime \prime}$ & $07^{\circ} 39^{\prime} 29^{\prime \prime}$ & Faro $(F)$ \\
\hline MIT13 & Mulata (Ml) & $37^{\circ} 06^{\prime} 58^{\prime \prime}$ & $07^{\circ} 39^{\prime} 29^{\prime \prime}$ & Loulé (L) & GIL128 & Galhosa (Gl) & $37^{\circ} 10^{\prime} 28^{\prime \prime}$ & $07^{\circ} 59^{\prime} 09^{\prime \prime}$ & Loulé (L) \\
\hline MlLg15 & Mulata (Ml) & $37^{\circ} 08^{\prime} 20^{\prime \prime}$ & $08^{\circ} 42^{\prime} 48^{\prime \prime}$ & Lagos (Lg) & CnT129 & Canela (Cn) & $37^{\circ} 06^{\prime} 58^{\prime \prime}$ & $07^{\circ} 39^{\prime} 29^{\prime \prime}$ & Tavira $(\mathrm{T})$ \\
\hline MIL16 & Mulata (Ml) & $37^{\circ} 10^{\prime} 50^{\prime \prime}$ & $07^{\circ} 59^{\prime} 21^{\prime \prime}$ & Loulé (L) & BrT130 & Brava (Br) & $37^{\circ} 05^{\prime} 53^{\prime \prime}$ & $07^{\circ} 41^{\prime} 08^{\prime \prime}$ & Tavira (T) \\
\hline MlL18 & Mulata (MI) & $37^{\circ} 10^{\prime} 06^{\prime \prime}$ & $07^{\circ} 57^{\prime} 18^{\prime \prime}$ & Loulé (L) & BrT131 & Brava $(\mathrm{Br})$ & $37^{\circ} 07^{\prime} 53^{\prime \prime}$ & $07^{\circ} 39^{\prime} 21^{\prime \prime}$ & Tavira (T) \\
\hline MISa20 & Mulata (Ml) & $37^{\circ} 08^{\prime} 02^{\prime \prime}$ & $07^{\circ} 49^{\prime} 59^{\prime \prime}$ & S.B. Alp. (Sa) & BrF133 & Brava $(\mathrm{Br})$ & $37^{\circ} 06^{\prime} 58^{\prime \prime}$ & $07^{\circ} 39^{\prime} 29^{\prime \prime}$ & Faro $(F)$ \\
\hline MIT21 & Mulata (Ml) & $37^{\circ} 05^{\prime} 22^{\prime \prime}$ & $07^{\circ} 41^{\prime} 19^{\prime \prime}$ & Tavira (T) & BeL134 & Spargale (Be) & $37^{\circ} 06^{\prime} 58^{\prime \prime}$ & $07^{\circ} 39^{\prime} 29^{\prime \prime}$ & Loulé (L) \\
\hline $\mathrm{MlO} 24$ & Mulata (Ml) & $37^{\circ} 06^{\prime} 58^{\prime \prime}$ & $07^{\circ} 45^{\prime} 47^{\prime \prime}$ & Olhão (O) & GlO135 & Galhosa (Gl) & $37^{\circ} 06^{\prime} 56^{\prime \prime}$ & $07^{\circ} 45^{\prime} 48^{\prime \prime}$ & Olhão (O) \\
\hline MlL25 & Mulata (Ml) & $37^{\circ} 13^{\prime} 13^{\prime \prime}$ & $08^{\circ} 05^{\prime} 00^{\prime \prime}$ & Loulé (L) & CvL137 & Costela Vaca (Cv) & $37^{\circ} 12^{\prime} 20^{\prime \prime}$ & $08^{\circ} 05^{\prime} 48^{\prime \prime}$ & Loulé (L) \\
\hline MIF26 & Mulata (Ml) & $37^{\circ} 05^{\prime} 56^{\prime \prime}$ & $07^{\circ} 50^{\prime} 59^{\prime \prime}$ & Faro $(\mathrm{F})$ & GIL138 & Galhosa (Gl) & $37^{\circ} 13^{\prime} 20^{\prime \prime}$ & $08^{\circ} 04^{\prime} 36^{\prime \prime}$ & Loulé (L) \\
\hline MlLg27 & Mulata (Ml) & $37^{\circ} 07^{\prime} 23^{\prime \prime}$ & $08^{\circ} 42^{\prime} 30^{\prime \prime}$ & Lagos (Lg) & PIL141 & Lagoinha (Pl) & $37^{\circ} 04^{\prime} 38^{\prime \prime}$ & $07^{\circ} 59^{\prime} 39^{\prime \prime}$ & Loulé (L) \\
\hline MIL30 & Mulata (MI) & $37^{\circ} 12^{\prime} 54^{\prime \prime}$ & $08^{\circ} 07^{\prime} 30^{\prime \prime}$ & Loulé (L) & BrT143 & Brava $(\mathrm{Br})$ & $37^{\circ} 05^{\prime} 57^{\prime \prime}$ & $07^{\circ} 40^{\prime} 52^{\prime \prime}$ & Tavira $(\mathrm{T})$ \\
\hline MlL33 & Mulata (Ml) & $37^{\circ} 13^{\prime} 20^{\prime \prime}$ & $08^{\circ} 06^{\prime} 21^{\prime \prime}$ & Loulé (L) & BrL144 & Brava (Br) & $37^{\circ} 04^{\prime} 39^{\prime \prime}$ & $07^{\circ} 59^{\prime} 40^{\prime \prime}$ & Loulé (L) \\
\hline MlL34 & Mulata (Ml) & $37^{\circ} 12^{\prime} 29^{\prime \prime}$ & $08^{\circ} 06^{\prime} 35^{\prime \prime}$ & Loulé (L) & PlLg145 & Lagoinha(Pl) & $37^{\circ} 08^{\prime} 11^{\prime \prime}$ & $08^{\circ} 42^{\prime} 41^{\prime \prime}$ & Lagos (Lg) \\
\hline MIF35 & Mulata (Ml) & $37^{\circ} 05^{\prime} 39^{\prime \prime}$ & $07^{\circ} 51^{\prime} 14^{\prime \prime}$ & Faro $(\mathrm{F})$ & BrL147 & Brava $(\mathrm{Br})$ & $37^{\circ} 06^{\prime} 58^{\prime \prime}$ & $07^{\circ} 39^{\prime} 29^{\prime \prime}$ & Loulé (L) \\
\hline MIL37 & Mulata (Ml) & $37^{\circ} 04^{\prime} 31^{\prime \prime}$ & $07^{\circ} 59^{\prime} 01^{\prime \prime}$ & Loulé (L) & AbL149 & Alfarroba Burro (Ab) & $37^{\circ} 06^{\prime} 58^{\prime \prime}$ & $07^{\circ} 39^{\prime} 29^{\prime \prime}$ & Loulé (L) \\
\hline MlO39 & Mulata (Ml) & $37^{\circ} 06^{\prime} 56^{\prime \prime}$ & $07^{\circ} 45^{\prime} 48^{\prime \prime}$ & Olhão (O) & BrF150 & Brava $(\mathrm{Br})$ & $37^{\circ} 05^{\prime} 58^{\prime \prime}$ & $07^{\circ} 50^{\prime} 56^{\prime \prime}$ & Faro (F) \\
\hline MlL40 & Mulata (Ml) & $37^{\circ} 12^{\prime} 27^{\prime \prime}$ & $08^{\circ} 06^{\prime} 38^{\prime \prime}$ & Loulé (L) & CvL151 & Costela Vaca (Cv) & $37^{\circ} 06^{\prime} 58^{\prime \prime}$ & $07^{\circ} 39^{\prime} 29^{\prime \prime}$ & Loulé (L) \\
\hline MIL41 & Mulata (Ml) & $37^{\circ} 12^{\prime} 18^{\prime \prime}$ & $08^{\circ} 07^{\prime} 13^{\prime \prime}$ & Loulé (L) & GIF152 & Galhosa (Gl) & $37^{\circ} 05^{\prime} 33^{\prime \prime}$ & $07^{\circ} 51^{\prime} 14^{\prime \prime}$ & Faro (F) \\
\hline GlL108 & Galhosa (Gl) & $37^{\circ} 10^{\prime} 20^{\prime \prime}$ & $07^{\circ} 57^{\prime} 35^{\prime \prime}$ & Loulé (L) & CvL154 & Costela Vaca (Cv) & $37^{\circ} 13^{\prime} 25^{\prime \prime}$ & $08^{\circ} 06^{\prime} 24^{\prime \prime}$ & Loulé (L) \\
\hline FgE109 & Flor Y Garrofa & $37^{\circ} 06^{\prime} 58^{\prime \prime}$ & $07^{\circ} 39^{\prime} 29^{\prime \prime}$ & Spain (E) & CeF155 & Costela Estoi (Ce) & $37^{\circ} 05^{\prime} 56^{\prime \prime}$ & $07^{\circ} 50^{\prime} 58^{\prime \prime}$ & Faro $(\mathrm{F})$ \\
\hline AbA111 & Alfarroba Burro (Ab) & $37^{\circ} 11^{\prime} 00^{\prime \prime}$ & $08^{\circ} 12^{\prime} 39^{\prime \prime}$ & Albufeira (A) & BrL157 & Brava $(\mathrm{Br})$ & $37^{\circ} 08^{\prime} 44^{\prime \prime}$ & $08^{\circ} 04^{\prime} 25^{\prime \prime}$ & Loulé (L) \\
\hline PILg112 & Lagoinha(Pl) & $37^{\circ} 07^{\prime} 22^{\prime \prime}$ & $08^{\circ} 42^{\prime} 28^{\prime \prime}$ & Lagos (Lg) & CeF158 & Costela Estoi (Ce) & $37^{\circ} 05^{\prime} 29^{\prime \prime}$ & $07^{\circ} 53^{\prime} 31^{\prime \prime}$ & Faro $(\mathrm{F})$ \\
\hline GlL113 & Galhosa (Gl) & $37^{\circ} 10^{\prime} 17^{\prime \prime}$ & $07^{\circ} 58^{\prime} 10^{\prime \prime}$ & Loulé (L) & CnSa159 & Canela $(\mathrm{Cn})$ & $37^{\circ} 07^{\prime} 55^{\prime \prime}$ & $07^{\circ} 50^{\prime} 01^{\prime \prime}$ & S. B. Alp. (Sa) \\
\hline GlL115 & Galhosa (Gl) & $37^{\circ} 06^{\prime} 58^{\prime \prime}$ & $07^{\circ} 39^{\prime} 29^{\prime \prime}$ & Loulé (L) & BrF162 & Brava (Br) & $37^{\circ} 05^{\prime} 29^{\prime \prime}$ & $07^{\circ} 53^{\prime} 31^{\prime \prime}$ & Faro $(\mathrm{F})$ \\
\hline BrS117 & Brava $(\mathrm{Br})$ & $37^{\circ} 06^{\prime} 58^{\prime \prime}$ & $07^{\circ} 39^{\prime} 29^{\prime \prime}$ & Silves (S) & BrLg164 & Brava $(\mathrm{Br})$ & $37^{\circ} 05^{\prime} 29^{\prime \prime}$ & $07^{\circ} 53^{\prime} 31^{\prime \prime}$ & Lagos (Lg) \\
\hline NgE118 & Negrette (Ng) & $37^{\circ} 06^{\prime} 58^{\prime \prime}$ & $07^{\circ} 39^{\prime} 29^{\prime \prime}$ & Spain (E) & AdF170 & Aida (Ad) & $37^{\circ} 06^{\prime} 58^{\prime \prime}$ & $07^{\circ} 39^{\prime} 29^{\prime \prime}$ & Faro $(\mathrm{F})$ \\
\hline
\end{tabular}

The two first letters of the code reference indicate the cultivar and the following letter(s) the origin region; DRAALG - Experimental field of Tavira; Geographic Location - Lat: $37^{\circ} 06^{\prime} 58^{\prime \prime} \mathrm{N}$; Long: $07^{\circ} 39^{\prime} 29^{\prime \prime} \mathrm{W}$. "Brava" = wild ungrafted tree. 


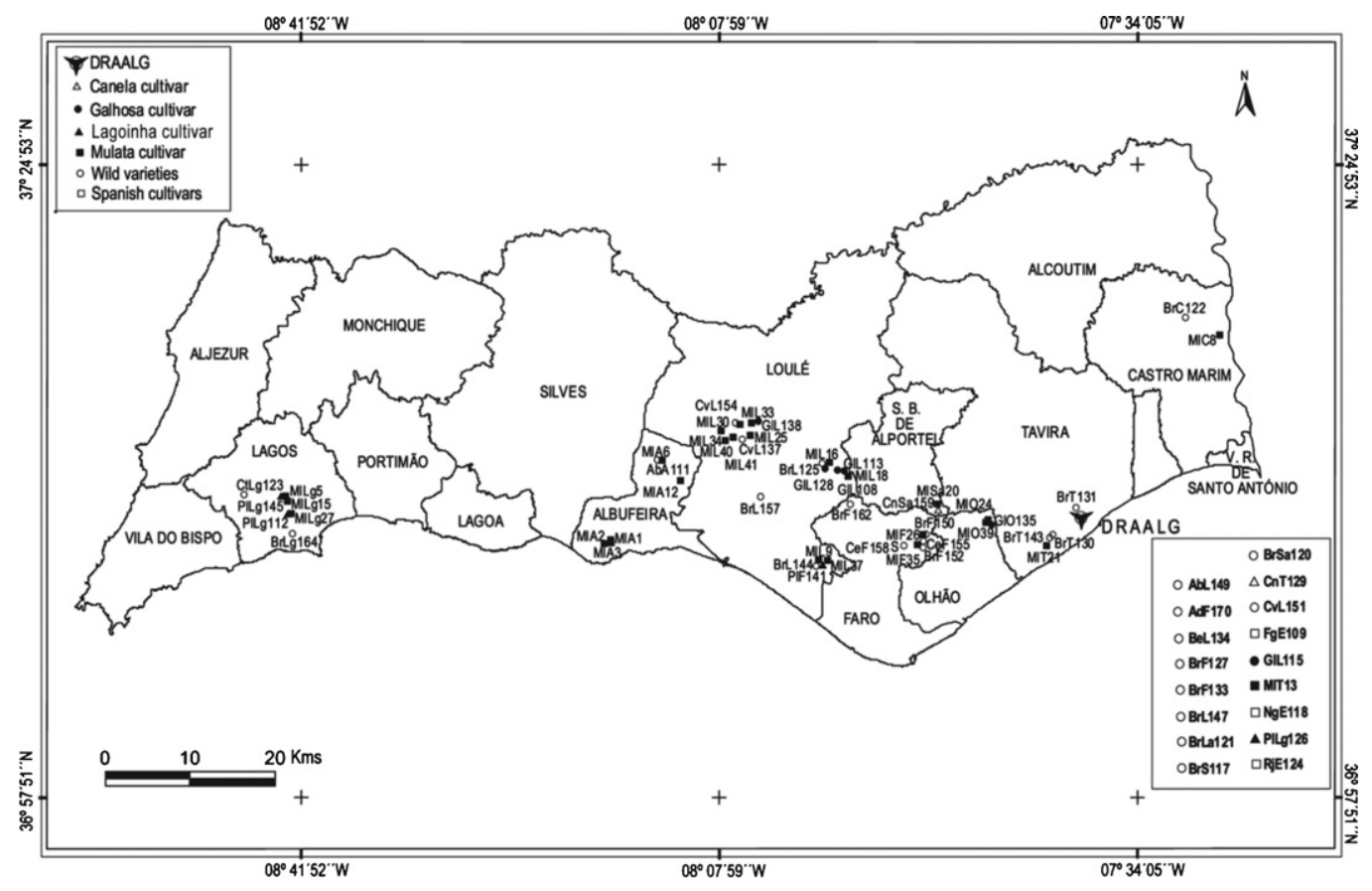

Fig. 1. Map of Algarve with the geographic location of the accessions used in the present study (the numbers refer to accessions listed in Table 1).

'Negrette' (118), a hermaphrodite cultivar 'Flor Y Garrofa' (109) and some wild trees from different regions $(117,120,121,127,133$ and 134). Accession designation (in brackets) and their provenance are listed in Table 1 . The geographic coordinate system used for the trees location shown in the map of Fig. 1, was the World Geodetic System 1984 (WGS84).

\subsection{Fruit morphological analysis}

Thirty-one fruit and seed characters (Table 2) from 68 accessions were analysed. The selection of the fruit pod and seed continuous characters was made by adapting the IPGRI descriptors (Battle and Tous, 1997) to numerical taxonomy methodology.

Table 2

List of fruit and seed descriptors observed in C. siliqua with mean values, standard deviation and range of the principal morphological characteristics in the 68 accessions

\begin{tabular}{|c|c|c|c|}
\hline Fruit and seed characters & Code & Mean \pm S.D. & Range \\
\hline 1. Length $(\mathrm{mm})$ & $\mathrm{L}$ & $163.2 \pm 19.7$ & $130.1-220.8$ \\
\hline 2. Linear length $(\mathrm{mm})$ & LL & $152.3 \pm 19.3$ & $121.1-204.4$ \\
\hline 3. Maximal width (mm) & MaW & $22.6 \pm 2.3$ & $16.0-28.1$ \\
\hline 4. Minimal width (mm) & MiW & $17.9 \pm 2.2$ & $13.0-23.9$ \\
\hline 5. Middle zone width ( $\mathrm{mm})$ & MzW & $21.3 \pm 2.3$ & $15.3-27$ \\
\hline 6. Maximal thickness (mm) & MaT & $10.0 \pm 1.2$ & $7.1-13.1$ \\
\hline 7. Minimal thickness (mm) & MiT & $7.7 \pm 1.1$ & $5.1-10.5$ \\
\hline 8. Middle zone thickness (mm) & MzT & $9.0 \pm 1.2$ & $5.4-11.7$ \\
\hline 9. Inter-ribe zone depth (mm) & IRD & $2.4 \pm 0.6$ & $3.7-1.0$ \\
\hline 10. Fruit weight $(\mathrm{g})$ & FWe & $17.7 \pm 3.7$ & $8.9-27.7$ \\
\hline 11. Length of false peduncle (mm) & $\mathrm{LP}$ & $8.1 \pm 1.4$ & $4.6-13.5$ \\
\hline 12. Width of false peduncle (mm) & WP & $2.9 \pm 0.4$ & $2.1-3.9$ \\
\hline 13. Number of seeds & NS & $11.2 \pm 1.6$ & $5-14$ \\
\hline 14. Number of aborted seeds & NA & $2.4 \pm 1.1$ & $1-9$ \\
\hline 15. Yield $(\%)$ & $\mathrm{Y}$ & $13.1 \pm 2.7$ & $7.5-21.3$ \\
\hline 16. Distance to the peduncle seed ( $\mathrm{mm})$ & DPS & $9.6 \pm 2.5$ & $5.4-15.8$ \\
\hline 17. Distance to the stigma seed $(\mathrm{mm})$ & DSS & $7.4 \pm 2.8$ & $4.2-20.1$ \\
\hline 18. Length of the peduncle seed ( $\mathrm{mm}$ ) & LPS & $8.54 \pm 0.57$ & $6.50-9.67$ \\
\hline 19. Width of the peduncle seed (mm) & WPS & $6.83 \pm 0.38$ & $5.90-7.73$ \\
\hline 20. Thickness of the peduncle seed ( $\mathrm{mm})$ & TPS & $4.39 \pm 0.36$ & $3.29-5.11$ \\
\hline 21. Weight of the peduncle seed $(\mathrm{g})$ & WePs & $0.189 \pm 0.03$ & $0.111-0.232$ \\
\hline 22. Length of the stigma seed ( $\mathrm{mm})$ & LSS & $8.51 \pm 0.61$ & 6.69-10.27 \\
\hline 23. Width of the stigma seed (mm) & WSS & $6.84 \pm 0.47$ & $5.64-7.68$ \\
\hline 24. Thickness of the stigma seed ( $\mathrm{mm})$ & TSS & $4.45 \pm 0.31$ & $3.50-5.21$ \\
\hline 25. Weight of the stigma seed $(\mathrm{g})$ & WeSS & $0.189 \pm 0.03$ & $0.116-0.241$ \\
\hline 26. Length of the middle seed ( $\mathrm{mm})$ & LMS & $9.52 \pm 0.54$ & $7.74-10.61$ \\
\hline 27. Width of the middle seed (mm) & WMS & $7.32 \pm 0.40$ & $6.26-8.00$ \\
\hline 28. Thickness of the middle seed ( $\mathrm{mm})$ & TMS & $4.29 \pm 0.38$ & $3.21-5.92$ \\
\hline 29. Weight of the middle seed (g) & WeMS & $0.221 \pm 0.02$ & $0.145-0.261$ \\
\hline 30. Total seed weight $(\mathrm{g})$ & TSWe & $2.26 \pm 0.4$ & 1.04-3.16 \\
\hline 31. Individual seed weight $(\mathrm{g})$ & ISWe & $0.204 \pm 0.02$ & $0.133-0.245$ \\
\hline
\end{tabular}


Twenty-five pods were randomly collected from each tree and 31 continuous characters were measured. Each fruit was manually decorticated and individually analysed for external and internal characteristics. The characters were coded as reported in Table 2.

\subsection{DNA extraction}

Young leaves were collected from each tree and stored at $-80{ }^{\circ} \mathrm{C}$ until extraction. DNA extraction for RAPD and AFLP analysis was performed on $100 \mathrm{mg}$ of leaves from each tree using the Dneasy ${ }^{\mathrm{TM}}$ Plant Mini Kit (QIAGEN Inc) according to the manu- facture's directions. The DNA extractions were stored at $-20{ }^{\circ} \mathrm{C}$ until required. Concentration and quality of DNA were determined by spectrophotometry.

\subsection{RAPD analysis}

PCR for RAPD (Williams et al., 1990) analysis was carried out in $25 \mu \mathrm{l}$ volumes containing $100 \mathrm{ng}$ genomic DNA, $0.20 \mu \mathrm{M}$ of each primer, $1 \mathrm{U}$ of Taq DNA polymerase (Roche), $200 \mu \mathrm{M}$ dNTPs (Roche), $10 \mathrm{mM}$ Tris $\mathrm{HCl}$ (pH 8.3), $50 \mathrm{mM} \mathrm{KCl,} 2.5 \mathrm{mM} \mathrm{MgCl}$. DNA amplification reactions were performed in a UNO II thermocycler

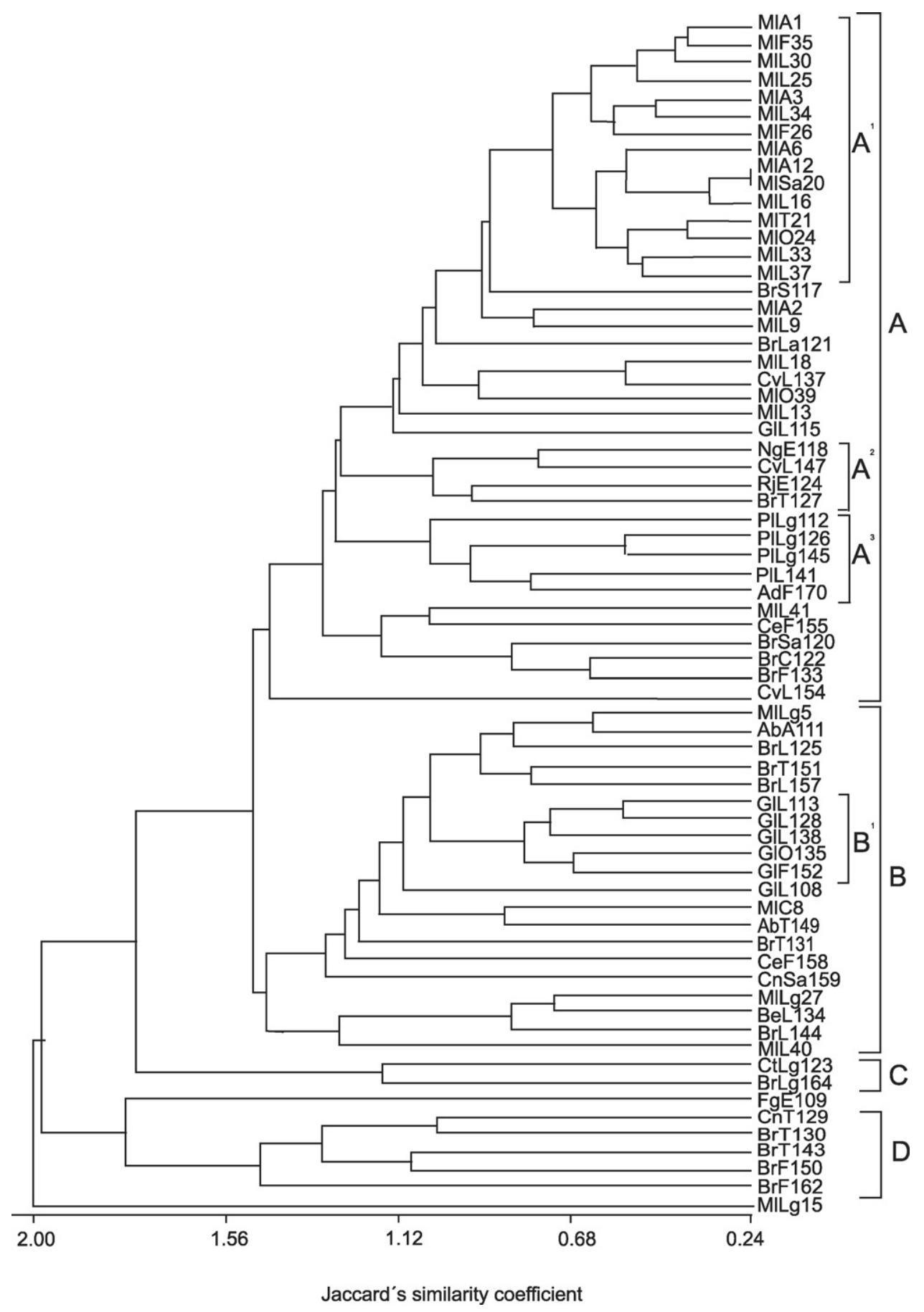

Fig. 2. Dendrogramme based on distance coefficients of the average results of 31 morphological fruit characters in 68 carob accessions (Cophenetic correlation $r=0.77$ ). The designations refer to accessions listed in Table 1 . The letters refer to the accession groups defined in the text. 
(Biometra) using the following cycling parameters: 45 cycles of $1 \mathrm{~min}$ at $94{ }^{\circ} \mathrm{C}, 1 \mathrm{~min}$ at $34^{\circ} \mathrm{C}$ and $1 \mathrm{~min}$ at $72^{\circ} \mathrm{C}$. A total of 100 primers were screened: 20 from each of the following sets OPA, OPB, OPC, OPD, OPI (Operon technologies, Alameda, California). Each amplification reaction was performed using a single primer and repeated in order to verify the reproducibility of the results. RAPD fragments were sized-fractionated on $1.2 \%$ agarose gels, stained with ethidium bromide and photographed on a digital gel documentation system. The nucleic acid markers $123 \mathrm{bp}$ (Sigma) and $1 \mathrm{~kb}$ (Invitrogen Life Technologies) were used.

\subsection{AFLP analysis}

AFLP analysis was performed according to Zabeau and Vos (1993). Primers, including one selective nucleotide (Eco + A and $M s e+C)$, were used for pre-amplification of the template. The genomic DNA digestion and the adaptor ligation were performed according to the protocol of AFLP Core Reagent Kit (Gibco BRL). Genomic DNA (600 ng) was restricted with EcoRI and MseI (2.5 U/ $\mu l$ each) in a restriction buffer ( $50 \mathrm{mM}$ TRIS-HCl pH 7.5, $50 \mathrm{mM}$ $\mathrm{Mg}$ acetate, $250 \mathrm{mM} \mathrm{K}$ acetate) in a total volume of $25 \mu \mathrm{l}$ (AFLP Core Reagent Kit, GIBCO BRL) for $2 \mathrm{~h}$ at $37^{\circ} \mathrm{C}$. After enzyme inactivation at $70{ }^{\circ} \mathrm{C}$ for $15 \mathrm{~min}$ EcoRI and Msel adapters were ligated to DNA digested fragments. The adapter-ligated DNA was pre-amplified using the following cycling parameters: 28 cycles of $30 \mathrm{~s}$ at $94^{\circ} \mathrm{C} ; 60 \mathrm{~s}$ at $56^{\circ} \mathrm{C}$ and $60 \mathrm{~s}$ at $72^{\circ} \mathrm{C}$. The pre-amplified DNA was diluted in a ratio of $1: 10$ and was used as a template for the selective amplification. This was performed with $\gamma-{ }^{33} \mathrm{P}-\mathrm{ATP}$ labelled primers Eco + ACC or Eco + ATG in combination with the unlabelled primers Mse + ATT, Mse + ACC, Mse + TGG. In the selective amplification four pair combinations of complementary primers were used: EcoRI and MseI, with three selective nucleotides in the $3^{\prime}$ end (I1-Eco-ACC/Mse-ATT, I2-Eco-ACC/ Mse-ACC, I3-Eco-ATG/Mse-ACC, I4-Eco-ACC/Mse-TGG). The cycling parameters were: 13 cycles with denaturation of $30 \mathrm{~s}$ at $94{ }^{\circ} \mathrm{C}$, primer annealing of $30 \mathrm{~s}$ at $65^{\circ} \mathrm{C}$. The annealing temperature was lowered by $0.7^{\circ} \mathrm{C}$ per cycle during the first 12 cycles until reaching $56{ }^{\circ} \mathrm{C}$. Polymerization of $60 \mathrm{~s}$ at $72^{\circ} \mathrm{C}$, and then 18 cycles of $30 \mathrm{~s}$ at $94{ }^{\circ} \mathrm{C}, 30 \mathrm{~s}$ at $56^{\circ} \mathrm{C}$ followed by polymerization $60 \mathrm{~s}$ at $72{ }^{\circ} \mathrm{C}$. The 30-330 bp nucleic acid marker (AFLP DNA Ladder Gibco BRL) was radioactively labelled with $\gamma-{ }^{33} \mathrm{P}$-ATP and T4 polynucleotide kinase, by incubating at $37{ }^{\circ} \mathrm{C}$ for $2 \mathrm{~h}$ in a UNO II Thermocycler (Biometra), followed by enzyme inactivation for $15 \mathrm{~min}$ at $70^{\circ} \mathrm{C}$. The samples were briefly centrifuged and maintained at $0{ }^{\circ} \mathrm{C}$ until use. After electrophoresis, the gels (6\% acrylamide) were dried and subsequently exposed to X-ray films (Kodak) for $48 \mathrm{~h}$ at room temperature.

\subsection{NTSYS analysis}

Mean morphological values of 31 continuous characters were used in the multivariate analysis in order to differentiate the cultivars (OTUs). The morphological characters were standardized before computation of the correlation and average taxonomic distance coefficients among OTUs. The OTUs were clustered by the unweighted pair group method using arithmetic average (UPGMA) and the results presented in the form of dendrogrammes. The cophenetic coefficient for the dendrogrammes was also computed as a measure of distortion of the clustering method used. Also a principal component analysis (PCA) was performed based on the correlations among the characters. Projections onto the first and second components of the OTUs, and of the original characters were also computed. RAPD and AFLP fragments in all accessions obtained with each primer or primer combination were assigned numbers $(1,2,3, \ldots, n)$ according to decreasing molecular weights. Each fragment was treated as a unit character and scored as present/absent in each accession and the data entered into a binary data matrix. Similarities among accessions were computed using Jaccard's coefficients. The accessions were clustered by the unweighted pair group method using arithmetic average (UPGMA) in order to present the results in the form of a dendrogramme as described by Sneath and Sokal (1973). The goodness of fit of the clustering to the data matrix was calculated by the COPH and MXCOMP programmes. Principal coordinate analysis (PCA) employed the DCENTER and EIGEN procedures. Also, a principal coordinate

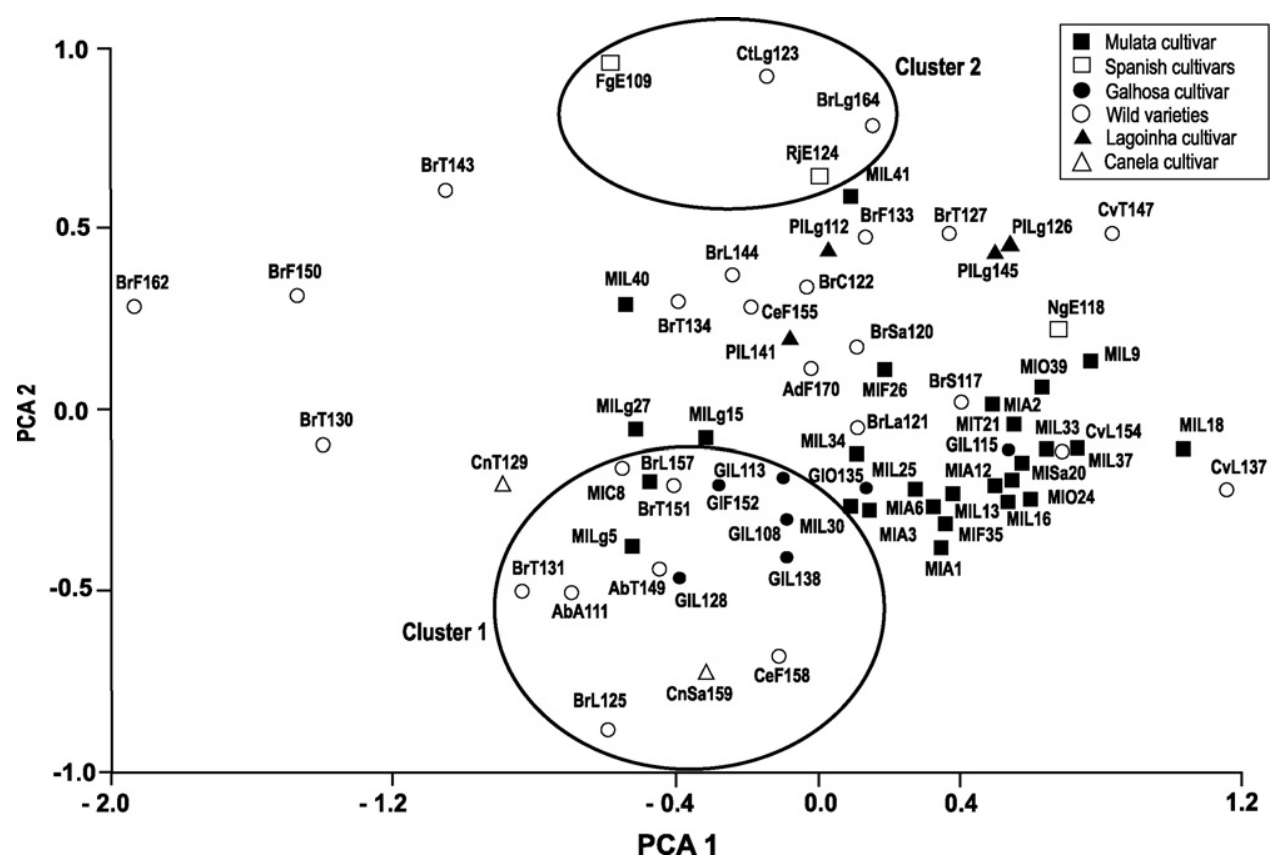

Fig. 3. Projection of the 68 carob trees and of the 31 seed and fruit morphological characters onto the plan defined by the principal components $1-2$. 
analysis (Gower, 1966) of the similarity matrix was performed, and the coordinates of the 68 accessions were computed for the two components. The Mantel test of significance (Mantel, 1967) was used to compare the similarity matrices produced by morphologic, AFLP and RAPD techniques. All computations were carried out using the NTSYS-pc software package (Version 2.02f, Rohlf, 1998).

The reliability and robustness of the RAPD and AFLP dendrogrammes were tested by bootstrap analysis with 1000 replications to assess branch support using the FreeTree programme (Pavlicek et al., 1999). In our study the limit of 50\% was used to assess the grouping of taxa statistically significant (Capo-chichi et al., 2001).

\section{Results}

\subsection{Fruit morphological analysis}

The range of the mean values of each of 68 accessions observed reveals a significant diversity in the morphological characters observed (Table 2).

The dendrogramme based on 31 continuous morphological characters (Fig. 2), shows four main clusters (A-D) that are identified at a distance coefficient of 1.35 , and are divided in several sub-groups. All 26 accessions from 'Mulata' cultivar except five trees are included in cluster A. Fifteen are clearly grouped in a sub-cluster $A^{1}$ and six are adjacent to this sub-cluster. All are

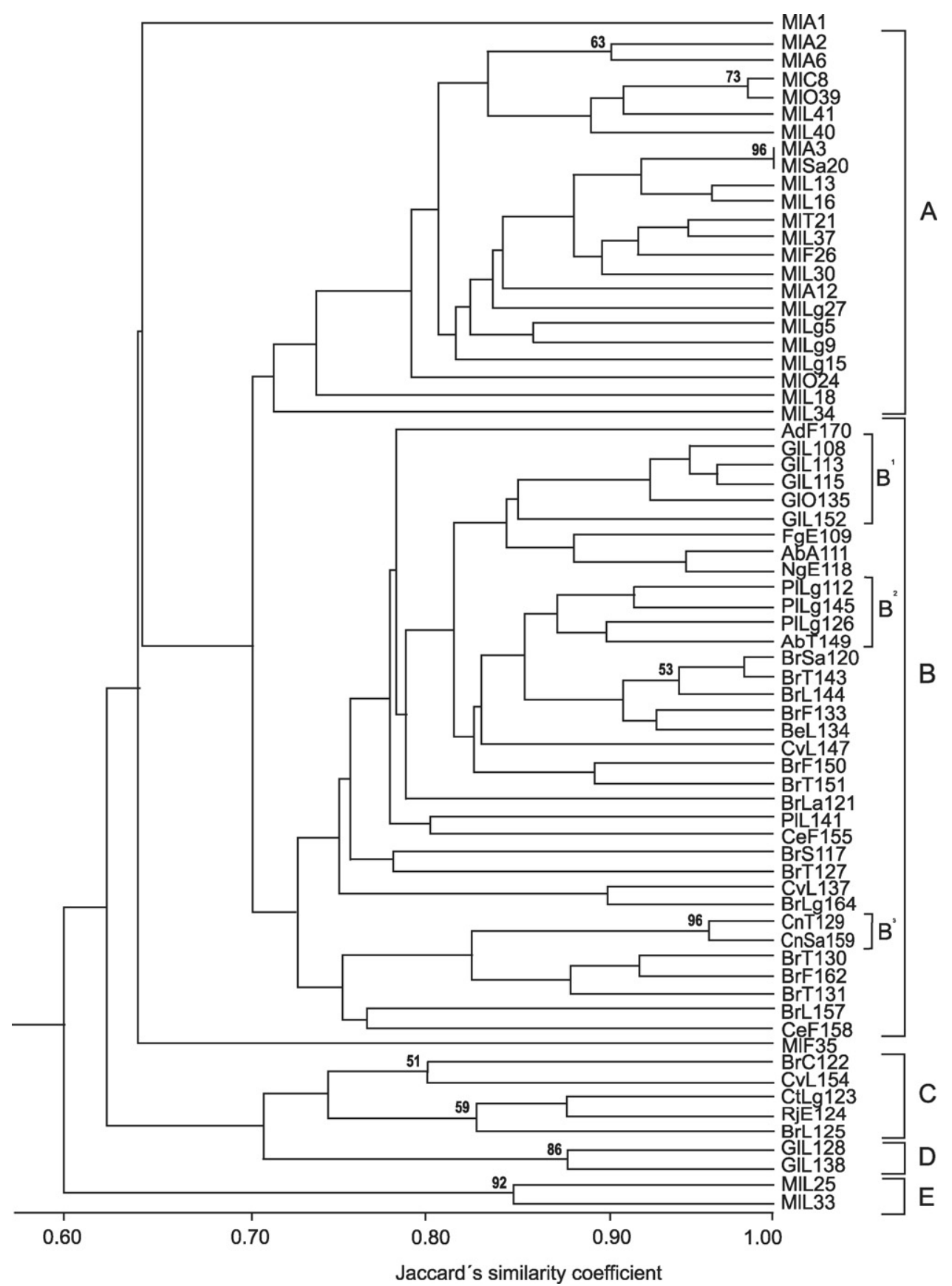

Fig. 4. Dendrogramme produced by Jaccard's coefficient and the UPGMA clustering method applied to 93 RAPD polymorphic fragments of 68 carob accessions (Cophenetic correlation $r=0.79$ ). The designations are according to accessions listed in Table 1 . 
geographically dispersed although located in six adjacent regions of the centre of Algarve. Five trees are dispersed over the dendrogramme outside cluster A; they are located in the Lagos region $(5,15,27)$, Castro Marim (8) and Loulé $(40)$. The sub-cluster $\mathrm{A}^{2}$ comprises four accessions all belonging to the experimental field of Tavira, of which two are the Spanish cultivars included in present study. All accessions of 'Lagoinha' and 'Aida' group together in sub-cluster $A^{3}$. Cluster $A$ still includes three accessions of 'Costela Vaca' $(137,147$ 154), one of 'Costela Estoi' cultivar (155) and four wild trees $(117,120,133,121)$. The cluster B is formed by several cultivars and some wild trees. All 'Galhosa' cultivars except one (115) are clustered in a sub-group $B^{1}$. This group includes accessions of 'Alfarroba Burro' (111, 149), 'Canela' (159), 'Costela Estoi' (158), 'Spargale' (134) and some wild trees from Loulé (157, $151,144,125,108)$, and Tavira (131). Four of the five 'Mulata' trees which fall outside the cluster $A$ are in this group. Group $C$ is formed exclusively by two accessions from Lagos $(123,164)$. A group D is formed by one accession of 'Canela' cultivar (129), belonging to the experimental field of Tavira and four accessions of wild trees, two from Tavira $(130,143)$ and two from Faro $(150,162)$. The cophenetic correlation value for morphological characters was $r=0.8$.

Principal component analysis (PCA) based on 31 fruit and seed morphologic characteristics on the planes defined by the components 1-2 does not form perfectly distinct groups (Fig. 3). However, a trend for grouping some trees according to their morphological features is observed. The first component accounting for $34.9 \%$ of separation is based on characters MaW, MzW, WeMS, WeSS, WePs, WMS, ISWe, FWe, MiW, LSS, WSS, LPS, WPS, LMS, MaT, MzT and MiT. 'Mulata', 'Negrette', 'Lagoinha' and 'Costela Vaca' cultivars characterized for having large fruits and heavy seeds show a tendency to group. Accessions 130, 143, 150 and 162 corresponding to wild trees appear clearly separated. The second component accounting for $14.8 \%$ of the separation based on characters TPS, IRD, DPS, TMS, FWe, LL, MiT, MzT, Y and L separates trees having high seed yield and thickness appropriate for industrial use $(5,8,108,111,113,125,128,131,138,149,151$, $152,157,158,159)$. Two Spanish cultivars $(109,124)$ and two accessions located in Lagos $(123,164)$, characterized by their low seed quality, appear clustered.

\subsection{RAPD analysis}

The polymorphism rates of RAPD primers were evaluated using eight main carob cultivars of Algarve: 'Galhosa', 'Spargale', 'Lagoinha', 'Canela', 'Aida', 'Gasparinha', 'Costela Canela', and 'Mulata'. An initial screening with one hundred RAPD primers allowed the selection of 25 that showed evidence of polymorphism. The total number of fragments produced was 338, of which 38 were polymorphic corresponding to $12 \%$ of polymorphism. The number of fragments per primer varied from 2 to 11 and their size ranged from 200 to $2000 \mathrm{bp}$.

For the analysis of the 68 accessions, 18 primers were selected on the basis of their ability to produce polymorphic and unambiguous markers (OPA-16; OPB-01; OPB-02; OPB-05; OPB10; OPB-11; OPC-01; OPC-04; OPC-05; OPC-09; OPC-11; OPC-15; OPD-08; OPD-20; OPI-02; OPI-15; OPI-18; OPI-19). They produced a total of 235 fragments of which 93 (40\%) were polymorphic and were used in the present analysis.

The dendrogramme produced by Jaccard's coefficient and the UPGMA clustering method applied to the RAPD analysis shows five main groups (A-E) that are identified at the 0.72 similarity level. In order to evaluate the robustness of the groups, a bootstrap analysis was performed to minimize the variance between accessions in each group (Fig. 4).

Group A contains all accessions of 'Mulata' cultivar excluding five accessions from Loulé (25, 33, 34), Albufeira (1) and Faro (35) regions. The accessions 2 and 6 from Albufeira region identified at 0.90 similarity level presented a high bootstrap value (63\%). Accessions 3 and 20 presented a very high bootstrap value of $96 \%$ although they were located $40 \mathrm{~km}$ apart. Group B is a heterogeneous group that includes several different cultivars and wild trees. Five accessions out of seven of 'Galhosa' cultivar form a subgroup $B^{1}$. All accessions of 'Lagoinha' cultivar are included in the sub-cluster $B^{2}$ excluding accession 141 . Accessions of 'Canela' cultivar are included in the sub-cluster $\mathrm{B}^{3}$ identified at 0.96

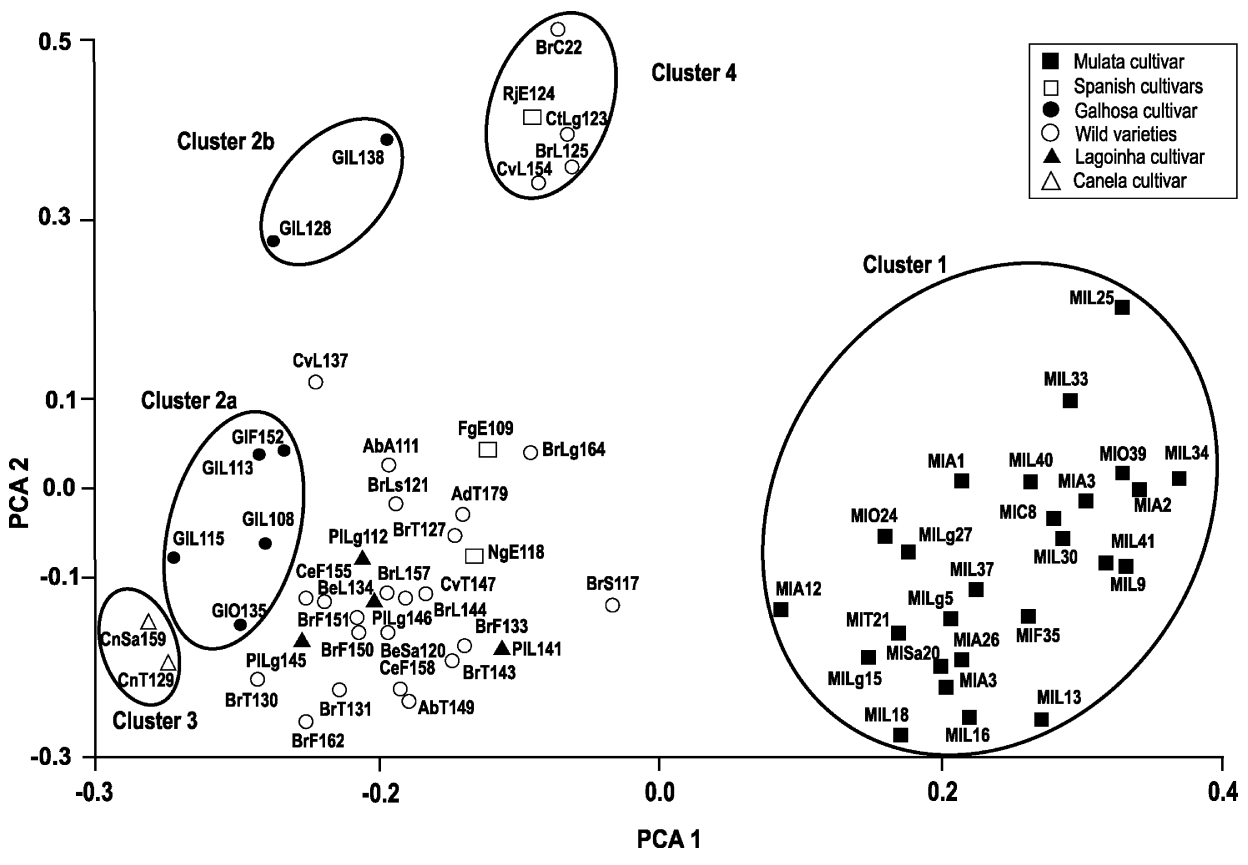

Fig. 5. Projection of the 68 carob trees based on 93 RAPDs polymorphic fragments onto the plan defined by the principal components $1-2$. 
similarity level, with a very high bootstrap value of $96 \%$. In the group B are still included all accessions of 'Alfarroba Burro' (111, 149), two Spanish cultivars 'Flor y Garrofa' (109) and 'Negrette' (118), two accessions of 'Costela Vaca' $(137,147)$, 'Spargale' (134), 'Aida' (170), 'Costela Estoi' $(155,158)$ and fourteen wild trees widely dispersed, from Tavira $(127,130,131,143,151)$, Faro (133, 150, 162), Lagos (164), São Brás de Alportel (120), Lagos (121), Silves (117) and Loulé $(144,157)$. Group $C$ is a highly heterogeneous group containing accessions from cultivars 'Costela Vaca' (154) 'Cutelôa' (123), 'Rojal' (124) and two wild trees from
Castro Marim (122) and Loulé (125). Group D is formed by two 'Galhosa' accessions from Loule $(128,138)$ identified at 0.88 similarity level, with a high bootstrap value of $86 \%$ and the group $E$ by two 'Mulata' accessions from Loulé $(25,33)$ identified at 0.85 similarity level, with a very high bootstrap value of $92 \%$.

Fig. 5 shows a principal component analysis (PCA) based on RAPD data set. Of the total variation, $15.2 \%$ is accounted for by the component 1 and $10.4 \%$ by the component 2. 'Mulata', 'Galhosa' and 'Canela' cultivars form three distinct clusters. Three different cultivars 'Cutelôa' (123), 'Rojal' (124), 'Costela Vaca' (154) and two

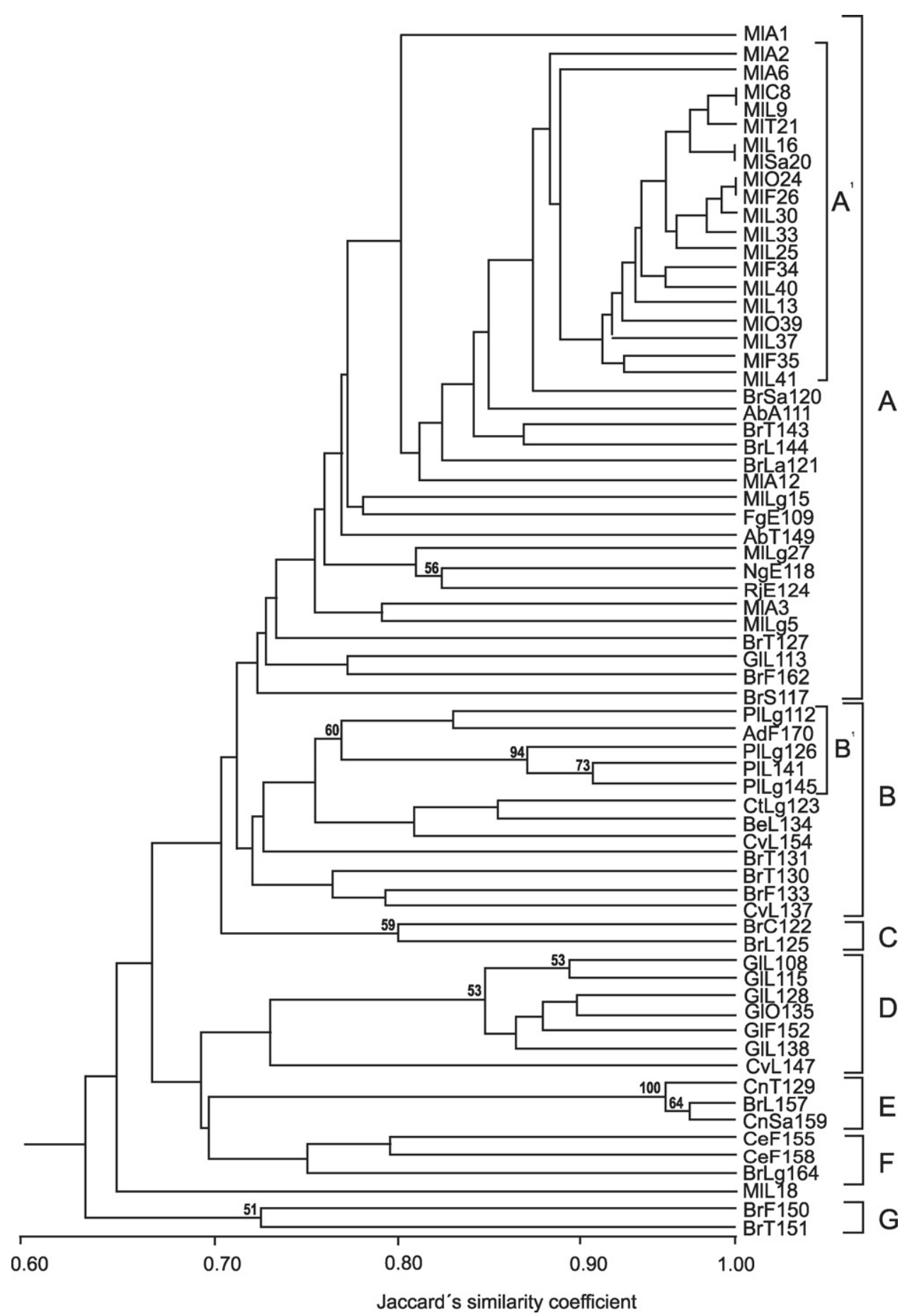

Fig. 6. Dendrogramme produced by Jaccard's coefficient and the UPGMA clustering method based on 110 AFLPs polymorphic fragments in 68 carob accessions. (Cophenetic correlation $r=0.90$.) The designations refer to accessions listed in Table 1 . 
wild accessions (122 and 125) are grouped in a single cluster. The Spanish cultivar 'Negrette' (118) makes the connection between the 'Mulata' and the remaining cultivars.

A specific RAPD marker for the 'Canela' cultivar was produced by primer OPB-11 (1480 bp). Eight primers out of 18 produced specific RAPD markers for carob genotypes. Primer OPB-05 produced two exclusive markers (1100 and $900 \mathrm{bp}$ ) for accession 138. The following primers produced an exclusive marker for each of the accessions indicated after brackets: OPA-16 (1100 bp)'Mulata' 35; OPB-10 (400 bp)-'Brava' 157; OPC-01 (600 bp)'Mulata' 1; OPC-05 (1470 bp)-'Brava' 127; OPC-09 (490 bp)-'Rojal' 124 and OPD-20 (600 bp)-'Costela Vaca' 151.

\subsection{AFLP analysis}

The AFLP analysis with four primer combinations generated 346 fragments of which 110 were polymorphic, corresponding to $31.8 \%$ of polymorphism. AFLP fragment sizes ranged approximately from 30 to $330 \mathrm{bp}$. Polymorphic fragments were distributed across the entire size range with the majority located within the range from 100 to $300 \mathrm{bp}$. The dendrogramme based on polymorphic fragments produced by Jaccard's coefficient and the UPGMA clustering method shows seven groups (A-G) that are identified at the 0.72 similarity level and are divided in several subclusters (Fig. 6). Group A contains all 'Mulata' cultivars, excluding accession 18 from Loulé. Nineteen accessions of this cultivar are clearly grouped in a sub-cluster $A^{1}$ and six are adjacent to this subcluster: three accessions from Albufeira $(1,3,12)$ and three from Lagos $(5,15,27)$. Group A comprises yet eight trees from experimental field of Tavira including the three Spanish cultivars $(109,118,124)$ and other four trees $(117,120,121,149)$. Group B comprises all 'Lagoinha' accessions that clearly separate in a subgroup $\mathrm{B}^{1}$ together with 'Aida' cultivar. Three accessions of 'Lagoinha' cultivar were identified at 0.88 similarity level, with a high bootstrap value of 94\%. Cultivars 'Cutelôa' (123), 'Spargale' (134), 'Costela Vaca' $(137,154)$ and three wild trees $(130,131,133)$ are also included in group B. Group C contains two wild accessions from distinct geographic origins, Castro Marim (122) and Loulé
(125) identified at 0.82 similarity level with a medium bootstrap value of 57\%. Group D contains all accessions belonging to 'Galhosa' cultivar excluding accession 113, and one accession of 'Costela Vaca' (147). Group $\mathrm{D}^{1}$ contains six accessions belonging to 'Galhosa' cultivar identified at 0.86 similarity level, with a high bootstrap value of $82 \%$. Group E contains all accessions of 'Canela' cultivar and a wild tree (157) identified at 0.98 similarity level and a bootstrap value of $100 \%$. Group $F$ contains all accessions of 'Costela Estoi' cultivar and a wild tree (164) from Lagos region. Group G includes two wild trees, one from Faro (150) and one from Tavira (151) identified at 0.73 similarity level with a medium bootstrap value of $52 \%$.

Fig. 7 shows a principal component analysis (PCA) based on AFLP data set. Of the total variation, $20.8 \%$ is accounted for by the component 1 and $7.6 \%$ by the component 2 . Seven accessions of 'Mulata' cultivar, geographically dispersed through Albufeira (1, 3, $12)$, Lagos $(5,15,27)$ and Loule (18) appear out of the 'Mulata' cluster. All accessions of 'Galhosa' cultivar except one (113), form a clearly isolated cluster. All accessions of 'Canela' cultivar cluster together with a wild tree (157). All accessions of 'Lagoinha' cultivar form a cluster together with the tree belonging to 'Aida' cultivar. The three accessions $(137,151,154)$ of 'Costela Vaca' cultivar are relatively close to each other. The PCA analysis essentially confirms the clusters produced by the UPGMA analysis. Cluster 1 is formed by all accessions but seven of 'Mulata' cultivar. All trees from 'Galhosa' cultivar are included in cluster 2 in the top of the projection. Cluster 3 is formed by two 'Canela' cultivars and one wild tree from Loule region morphologically very similar with 'Canela'. The last cluster placed on the bottom includes all accessions of 'Lagoinha' and 'Aida' cultivars (Fig. 5).

Specific AFLP markers for carob individuals were produced by different primer combinations. Combination I1 produced exclusive markers for accessions 37 (40 bp) and 150 (65 bp). Combination I2 produced several exclusive markers for accessions 3 (300, 200 and $120 \mathrm{bp}$ ), and 18 (220 bp) belonging to 'Mulata' cultivar. With combination I3 one exclusive marker for accession 18 (145 bp) was obtained. No specific AFLP markers were obtained for carob cultivars.

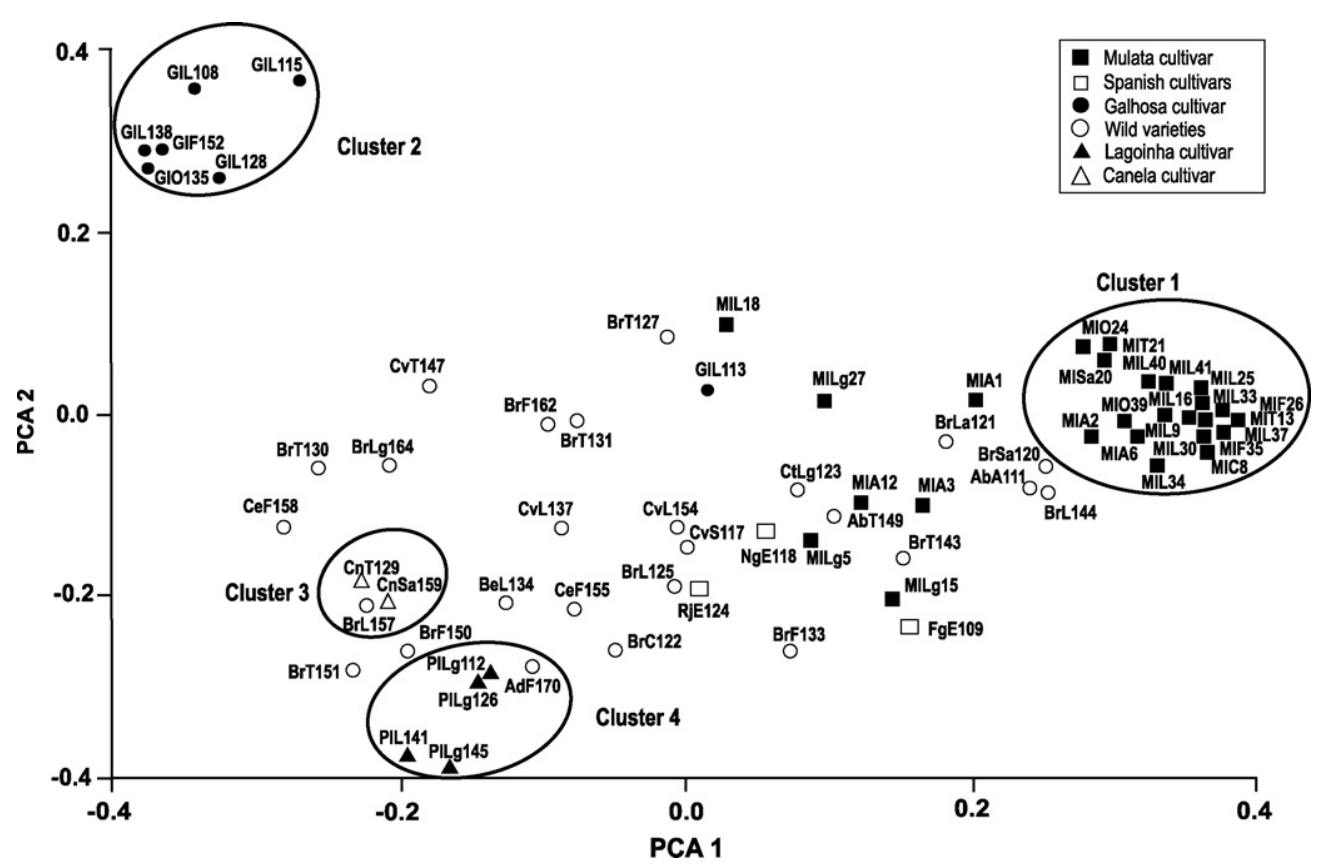

Fig. 7. Projection of the 68 carob trees based on 110 AFLPs polymorphic fragments onto the plan defined by the principal components $1-2$. 


\section{Discussion and conclusions}

In the present study the genetic diversity of $C$. siliqua was assessed for the most typical cultivars of Algarve and for wild ungrafted trees geographically dispersed all over the region. For each cultivar two or more individuals were genotyped except for 'Aida' which is a single tree discovered in the 1980s. 'Mulata' cultivar has been extensively used as source of the domestication process. Moreover, the geographic distance from the centre of origin and the relative homogeneity of environmental factors may contribute to limit the actual genetic diversity of this taxon in Algarve. An expressive number of accessions of the most widespread cultivar, 'Mulata' from different geographic locations were evaluated to estimate the genetic diversity within this cultivar. In order to evaluate the level of biodiversity and the natural evolution of $C$. siliqua wild ungrafted trees were included in this study. Wild trees have a promising industrial interest because they produce a higher content of galactomannans than traditional cultivars (Winer, 1980).

The characters analysed in the present work are not fully identical with those traditionally used for the identification of carob varieties. The characters used in this study were directed to the evaluation of agro-industrial yield with the exclusion of seed and fruit colour, and seed episperm roughness. Significant specific morphological differences, namely at fruit and seed levels were found (Table 2). The morphometric study performed on fruits and seeds of these accessions appear to be determinant to define a selection strategy directed to agro-industrial applications. Normally, in traditional cultivars (namely 'Mulata') the kernels represent about $10 \%$ of the total carob bean weight. However, in wild ungrafted trees this value could be largely exceeded. The content of LBG extracted from the endosperm of seeds is the most important product in the carob bean and it could range from 28 to $40 \%$ in weight, depending on the cultivar or variety and the climatic conditions (Brito de Carvalho, 1988). The results here presented, obtained on the basis of numerical taxonomy analysis, show that trees with the best seed yield were grouped in cluster B (Fig. 2). Only two trees $(5,8)$ out of 24 belonging to 'Mulata' cultivar fall in this group. This cultivar is the more extensively used due to its agronomic features and fruit weight, and is, however, medium in seed yield. Therefore, trees of group B should be considered as potential candidates for genetic improvement and should be included in future breeding programmes.

The domestication process appears along component 1 in the projection of the fruit morphological characters (Fig. 3). Domesticated trees having larger fruit and seeds and low seed yield are restricted to the right side of the plan defined by the two principal components $1-2$, while wild trees (namely $130,143,150,162$ ) and the hermaphrodite cultivar (109) are projected on the opposite side of the plan.

Comparative studies using RFLP, RAPD, AFLP and microsatellites have shown that AFLP is the most efficient method to estimate genetic diversity because of its high reproducibility and multiplex ratio (Powell et al., 1996; Russel et al., 1997; Pejic et al., 1998). These authors also reported that the estimates based on RFLP, AFLP and microsatellites are highly correlated, whereas the correlations of RAPD marker data with the other three types of markers were significantly lower. AFLP generally reveals more polymorphisms than RAPD and is a more reliable and robust genetic molecular-marker assay (Lin et al., 1996; O'Neill et al., 1997; Ude et al., 1999). The results obtained were evaluated based on the known geographic origins and fruit and seed characteristics of the Portuguese cultivars (Barracosa et al., 2007). AFLP and RAPD analyses with $40 \%$ and $32 \%$ of polymorphism, respectively, showed to be consistent with fruit and seed characteristics and allowed to estimate the genetic relationships in carob cultivars. However, AFLP analysis in this study was a more reliable and robust genetic molecular-marker assay with higher bootstrap values for each group. The dendrogramme based on polymorphic fragments produced by Jaccard's coefficient and the UPGMA clustering method shows seven groups in the AFLP analysis and five main groups in RAPD analysis identified at the same similarity level (0.72). The cophenetic correlation values for AFLP and RAPD, respectively $r=0.9$ and $r=0.8$ showed that the genetic clusters accurately represent the estimates of genetic similarity. However, the Mantel test product moment correlation value $(r=0.23, P=0.05)$ showed that there was no relationship between the AFLP and RAPD similarity matrices. Nevertheless, in both AFLP and RAPD analysis, carob accessions belonging to cultivars 'Galhosa', 'Canela', 'Lagoinha', 'Costela Estoi' and 'Mulata' cluster according to the respective cultivar with a few exceptions. For example, in the AFLP analysis the accession 18, having the largest fruits and seeds (data not shown) is clearly isolated from the 'Mulata' cluster. In RAPD analysis this accession, although not completely separated from the group, appears in an edge position. A geographic pattern of distribution is observed by the AFLP analysis for 'Mulata' accessions. Trees from Lagos and Albufeira regions appear separated in the projection of polymorphic fragments (Fig. 7) from trees of central regions-Faro, Tavira and Loulé. They probably could be considered as distinct ecotypes of 'Mulata' cultivar.

In both genetic analysis, six 'Galhosa' cultivar accessions from different geographic origins appear grouped. For this cultivar, AFLP analysis presented a very high bootstrap value (86\%). However, for RAPD analysis a high bootstrap value (82\%) was obtained just for two accessions of 'Galhosa' cultivar (128 and 138 ) from Loulé. Nevertheless, it was not possible to find a specific genetic marker due to the observed significant intra-cultivar polymorphism. According to the AFLP and RAPD analyses 'Galhosa' is the more distant cultivar from 'Mulata' and the closest to the wild trees. Comparison of phenotypic features agrees with this separation (data not shown). 'Lagoinha' and 'Aida' cultivars are genetically very close according to AFLP and RAPD analyses. Morphological analysis also confirms the proximity between these cultivars characterized by long and heavy fruits with a high number of seeds of good quality (Barracosa et al., 2007). AFLP analysis presented a very high bootstrap value (94\%) for three accessions of 'Lagoinha'. However, RAPD analysis presented a low bootstrap value (43\%) just for two accessions (112 and 145) of this cultivar from Lagos.

AFLP and RAPD analyses show that 'Canela' is apparently the most genetically homogeneous cultivar with bootstrap values of $100 \%$ and $96 \%$ respectively, and it could be identified by a specific RAPD marker, the OPB-11 (1480 bp). This cultivar has particular fruit and seed characteristics with light brown seeds and fruits with very high yield of seeds (Barracosa et al., 2007). 'Cutelôa' (123), 'Rojal' (124), 'Costela Vaca' (154) cultivars and two wild trees $(122,125)$ form a clearly isolated cluster in the RAPD analysis and are close to each other and centred in the projection plan in the AFLP analysis. Within this morphological heterogeneous group coexist the longest fruit (123), the widest fruit (154) and the fruit with the highest number of seeds (124). As in other species this may suggest that these accessions are a potential source of genes useful for widening the genetic base of breeding populations (Ude et al., 2003). Two wild accessions (150 and 151) morphologically well distinct are relatively close to each other in the two genetic analyses with the RAPD showing a higher similarity coefficient (87\%) than the AFLP (73\%). 'Spargale', 'Lagoinha', 'Aida' and 'Canela' 
cultivars lie close to each other in the two genetic analyses. These cultivars possess a high number of ovules. Owing to this interesting feature these cultivars should be considered for genetic improvement.

Identification of a specific cultivar with DNA markers might be a difficult task due to the introduction in this study of a large number of wild accessions. A number of specific DNA markers were, nevertheless identified of which one was cultivar-specific. Seven AFLP and nine RAPD specific markers were found for individual trees and one specific RAPD marker was identified for 'Canela' cultivar. The DNA markers used in this study were able to clearly differentiate the principal carobs cultivars of Algarve, 'Canela', 'Galhosa', 'Lagoinha' and 'Mulata', into their distinct morphogroups based on fruit and seed characteristics (Barracosa et al., 2007). We concluded that cultivar is determinant for group discrimination instead of geographic localization. No distinct group related to localization was observed for 'Mulata' cultivar which has a high number of accessions distributed all over the Algarve region.

AFLP, with higher bootstrap values, revealed more suitable than RAPD for the construction of a carob phylogenetic tree. The AFLP analysis aggregates the different trees of "Galhosa", "Lagoinha" and "Canela" cultivars, suggesting a relatively recent and probably clonal dispersion. The low bootstrap values on "Mulata" cultivar suggested a more ancient dispersion.

The present contribution shows that AFLP is a promising approach to help in carob breeding programmes aiming at the development of varieties directed to agro-industrial applications while keeping biodiversity at a high level. It points to the need for a more extensive study to be developed all over the Mediterranean basin, between quantitative traits and molecular markers for a better and efficient conservation (Makrem et al., 2006).

\section{Acknowledgments}

This work was funded by the Foundation for Science and Technology (FCT), programme PRAXIS XXI/BD/3601/94. P.B. thanks ESF (EC-I) Framework programme for his PhD grant).

\section{References}

Alali, F.Q., Tawaha, K., El-Elimat, T., Syouf, M., El-Fayad, M., Abulaila, K., Nielsen, S.J., Wheaton, W.D., Falkinham III, J.O., Oberlies, N.H., 2007. Antioxidant activity and total phenolic content of aqueous and methanolic extracts of Jordanian plants: an ICBG project. Nat. Product Res. 21 (12), 1121-1131.

Battle, I., Tous, J., 1997. Carob Tree. Ceratonia siliqua L. Promoting the Conservation and Use of Underutilized and Neglected Crops. Institute of Plant Genetics and Crop Plant Research, International Plant Genetic Resources Institute, Rome, Italy.

Barracosa, P., Graça, J., 2006. Fichas de caracterização - Alfarrobeira. In: Caracterização de variedades regionais Portuguesas. Ministério da Agricultura, do Desenvolvimento Rural e Pescas. Direcção-Geral de Protecção das Culturas, Oeiras, Portugal, pp. 1-16.

Barracosa, P., Osório, J., Cravador, A., 2007. Evaluation of fruit and seed diversity and characterization of carob (Ceratonia siliqua L.) cultivars in Algarve region. Sci. Horticult. 114, 250-257.

Batista, M.T., Amaral, M.T., Proença Da Cunha, A., 1996. Carob fruits as source of natural oxidants. In: Communication in 3rd International carob symposium, Tavira, Portugal, 19-23 June.
Brito de Carvalho, J.H., 1988. Criteria for evaluation of carob varieties. In: Proceedings of the II International Carob Symposium, Valencia, Spain, September 29October 1 , pp. 558-566.

Capo-chichi, L.J.A., Weaver, D.B., Morton, C.M., 2001. AFLP assessment of genetic variability among velvetbean (Mucuna sp.) accessions. Theor. Appl. Genet. 103, 1180-1188.

Graça, J., Custódio, S., 2000. Caracterização da Fileira da Alfarroba. In: Sistemas Agrários Tradicionais no Algarve, Contributos para o seu Estudo. Direcção Regional de Agricultura do Algarve, Faro, Portugal, pp. 99-157.

Gower, J.C., 1966. Some distance properties of latent root and vector methods used in multivariate analysis. Iometrika 53, 325-338.

Lin, J.J., Kuo, J., Ma, J., Saunders, J.A., Beard, H.S., Macdonald, M.H., Kenworthy, W., Ude, G.N., Matthews, B.F., 1996. Identification of molecular markers in soybean comparing RFLP, RAPD and AFLP DNA mapping techniques. Plant Mol. Biol. Rep. $14,156-169$

Makrem, A., Najed, B.F., Laarbi, K.M., Boussaid, M., 2006. Genetic diversity in Tunisian Ceratonia siliqua L. (Caesalpinioideae) natural populations. Genet. Resour. Crop Evol. 53, 1501-1511.

Mantel, N., 1967. The detection of disease clustering and a generalized regression approach. Cancer Res. 27, 209-220.

Makris, D., Kefalas, P., 2004. Carob pods (Ceratonia siliqua L.) as a source of polyphenolic antioxidants. Food Technol. Biotechnol. 42 (2), 105-108.

Nienhuis, J., Slocum, M.K., De Vos, D.A., Muren, R., 1993. Genetic similarity among Brassica oleraceae genotypes as measured by restriction fragment lenght polymorphisms. J. Am. Soc. Horticult. Sci. 118, 298-303.

O’Neill, N.R., van Berkum, P., Lin, J.J., Kuo, J., Ude, G.N., Kenworthy, W., Saunders, J.A., 1997. Application of amplified restriction fragment length polymorphism for genetic characterization of Colletotrichum pathogens of Alfalfa. Phytopathology $87,745-750$.

Pavlicek, A., Hrda, S., Flegr, J., 1999. Freetree - Freeware program for construction of phylogenetic trees on the basis of distance data and bootstrap/jackknife analysis of the tree robustness. Application in the RAPD analysis of the genus Frenkelia. Folia Biol. (Praha) 45, 97-99.

Pejic, I., Ajmone-Marsan, P., Morgante, M., 1998. Comparative analysis of genetic similarity among maize inbred lines detected by RFLPs, RAPDs, SSRs and AFLPs. Theor. Appl. Genet. 97, 1248-1255.

Powell, W., Morgante, M., Andre, C., Hanafey, M., Vogel, J., Tingey, S., Rafalasky, A., 1996. The comparison of RFLP, RAPD, AFLP and SSR (microsatellite) markers for germplasm analysis. Mol. Breed 3, 225-238.

Rohlf, F.J., 1998. NTSYS-pc Numerical Taxonomy and Multivariate Analysis System. vers. 2. 02f Exeter Software. Setauket, New York, USA.

Russel, J.R., Fuller, J.D., Macaulay, M., Hatz, B.G., Jahoor, A., Powell, W., Waugh, R., 1997. Direct comparison of the levels of genetic variation among barley accessions detected by RFLPs, AFLPs, SSRs and RAPDs. Theor. Appl. Genet. 95, 714-722.

Sneath, P.H.A., Sokal, R.R., 1973. Numerical Taxonomy. Freeman, London.

Talhouk, S.N., Breugel, P., Zurayk, R., Al-Khatib, A., Estephan, J., Ghalayini, A., Debian, N., Lychaa, D., 2005. Status and prospects for the conservation of remant seminatural carob Ceratonia siliqua L. populations in Lebanon. Forest Ecol. Manage. 206, 49-59.

Tous, J., Olarte, C., Truco, M.J., Arús, P., 1992. Isozyme polymorphisms in carob cultivars. Hortscience 27 (3), 257-258.

Tous, J., Battle, I., 1990. El Algarrobo. Ed. Mundi-Prensa, Madrid, Spain.

Ude, G.N., Devine, T.E., Kuykendall, L.D., Mathews, B.F., Saunders, J.A., Kenworthy, W., Lin, J.J., 1999. Molecular mapping of the soybean nodulation gene, Rj4. Symbiosis 26, 101-110.

Ude, G., Pillay, M., Ogundiwin, E., Tenkouano, A., 2003. Genetic diversity in an Africain plantain core collection using AFLP and RAPD markers. Theor. Appl. Genet. 107 (2), 248-255.

Zabeau, M. Vos, P., 1993. Selective restriction fragment amplification: a general method for DNA fingerprinting. European Patent Application 924026 2.7. Publication number 0534858A1.

Zohary, M., 1973. Geobotanical Foundations of the Middle East, 2 vols. Stuttgart

Vourdoubas, J. Makris, P., Kefalas, J. Kaliakatsos, G, 2002. In: Proceedings of the 12th National Conference and Technology Exhibition on Biomass for Energy, Industry and Climate Protection, Amsterdam, pp. 489-493.

Williams, J.G.K., Kubelik, A.R., Liva, K.J., Rafalsky, J.A., Tingey, S.V., 1990. DNA polymorphisms amplified by arbitrary primers are useful as genetic markers. Nucleic. Acids Res. 18, 6531-6535.

Winer, N., 1980. The potential of the carob (Ceratonia siliqua). Int. Tree Crops J. 1, 1526. 